\title{
US Congress prepares new rules
}

\section{Washington}

AN obscure decennial ritual that will determine who pays in the case of a nuclear accident is about to begin again. The Price-Anderson Act, which sets a limit on the financial liability of nuclear utilities, expires next year; lobbying by industry and its opponents is already shifting into high gear

The act, first passed in 1957, was designed to remove a major obstacle to the adoption of nuclear power by electric utilities: the risk of a crippling financial burden in the event of a catastrophic nuclear accident. The act removes the right of injured parties to sue anyone but the utility, and places a limit on the liability of utilities. (The figure depends on the number of licensed reactors in the country; it is currently $\$ 630$ million.)

In its original form the act provided for the federal government to play the role of chief insurer. That provision was altered when the bill came up for renewal in 1967 and 1977 and each utility is now required to carry $\$ 160$ million in insurance; in addition, if an accident occurs that causes damage in excess of that amount, each reactor will be assessed up to $\$ 5$ million - a sort of after-the-fact insurance premium. The federal government is now liable only for accidents at its own facilities, and only up to $\$ 500$ million.

Industry, in pressing for a renewal of the act, argues that it is not a subsidy to the nuclear power industry, but rather a form of "no-fault" insurance, akin to worker's compensation. Without the liability limit. industry argues, victims of an accident might receive even less - judgements of more than a few hundred million dollars would bankrupt the average utility.

Critics point out, simply, that a major accident could easily cause damage to the extent of tens of thousands of millions of dollars; they claim that by shielding the industry from this risk, the act skews economic incentives to increase safety.

Opposition is also emerging from states that are candidates to receive federally operated depositories for high-level reactor waste, as the act limits the amount that victims of an accident at such a facility can recover to $\$ 500$ million.

Even if Congress fails to renew the act. however, the reactors already licensed would probably continue to enjoy the protection of the act. US courts have long held that legislation such as the PriceAnderson Act represents a financial contract that cannot be undone by subsequent legislation. At issue is whether new reactors coming on line after 1 August 1987 will be covered.

Several bills have already been filed in Congress:

OSimpson-McClure (S 1225) would maintain the basic framework of the act while increasing the liability limit to $\$ 2,000$ million.

OMorrison (HR 2524) would provide for full compensation for any accident involving high-level waste.

OHart (S 445) would repeal the liability limit while retaining the current insurance scheme; victims would be free to sue any liable party if damages exceed $\$ 630$ million.

Another alternative, endorsed by the Nuclear Regulatory Commission, would provide full compensation to victims by assessing after-the-fact premiums from all reactors at $\$ 5$ million a year for as long as it takes Stephen Budiansky

\section{Genetic engineering \\ Rifkin set back}

Washington

THE US District Court of the District of Columbia has denied the latest attempt by anti-genetic-engineering activist Jeremy Rifkin to put legal obstacles in the way of a deliberate release experiment. Judge Aubrey Robinson ruled that the National Institutes of Health (NIH) could not, as requested by Rifkin, be compelled to regulate a proposed field test of a genetically modified bacterium intended to protect crops against frost damage. The experiment, proposed by Advanced Genetic Sciences Inc., has now been submitted instead to the Environmental Protection Agency (EPA).

The experiment was recommended for approval in June 1984 by NIH's Recombinant DNA Advisory Committee (RAC), but the director of NIH withheld his approval to avoid applying different standards to private companies, as opposed to academic researchers: a previous injunction forbade NIH to approve an almost identical experiment by Stephen Lindow of the University of California until NIH prepared an environmental impact statement.

Dismayed by the legal circus surrounding the Lindow proposal and the prospect of long delays, Advanced Genetic Sciences withdrew its application (which was in any case only voluntary) and went to EPA, which has claimed legal authority over deliberate releases of some recombinant organisms.

Rifkin petitioned the court to rule RAC's original recommendation of the Advanced Genetic Sciences experiment invalid, on the basis of obscure legal technicalities; he then sought to compel NIH to forbid it.

In dismissing both petitions, Judge Robinson made plain his puzzlement with Rifkin's argument, and the experiment now lies firmly in the lap of EPA.

Tim Beardsley
Leprosy vaccine

\section{Malawi trial to be launched}

Although more money has yet to be found, the British Leprosy Relief Association (LEPRA) has announced the launch of a full-scale trial of a newly developed leprosy vaccine in northern Malawi in 1986 in conjunction with the government of Malawi, the London School of Hygiene and Tropical Medicine (LSHTM) and the World Health Organization (WHO).

About 15 million people suffer from leprosy, and although drug treatment is available, it can be very slow and often too late to prevent irreversible neural damage. Excitement is understandable at the development of a potential vaccine, which has been made possible largely by the collaborative efforts of a group of scientists within the WHO Special Programme for Research and Training in Tropical Diseases (TDR) coordinated by Dr Barry Bloom of Albert Einstein College of Medicine, New York

The vaccine consists of heat-killed Mycobacterium leprae, the causative agent of the disease. purified from the tissues of the nine-banded armadillo, the best animal host for growing large numbers of bacteria which cannot be grown in vitro. Four colonies of armadillos are maintained by TDR for this purpose. Safety trials have been completed in Norway, where leprosy was eradicated as recently as 1950, and a large-scale nonrandom trial of 60,000 leprosy contacts is under way in Venezuela which will be completed later this year.

The Karonga district of Malawi has been chosen for the first population-wide trial largely because prevalence of the disease is rather high (1-2 per cent) and because of the groundwork laid by LEPRA's comprehensive evaluation programme in this region directed by Dr J.M. Ponninghaus and coordinated by $\mathrm{Dr} P$. Fine of LSHTM. Over the past six years, at a cost of approximately $\$ 500,000$, all 120,000 residents of the region have been examined and interviewed, and improved serological tests have been developed. About 1,700 leprosy cases are present and up to 240 new ones have appeared each year

There is evidence from earlier trials that vaccination with Bacille Calmette-Guérin (BCG) against tuberculosis can provide some protection against leprosy and, indeed, animal experiments and therapeutic work in Venezuela suggest a vaccine containing both killed $M$. leprae and BCG is most promising. The aim therefore is essentially to compare this mixed vaccine with $\mathrm{BCG}$ alone in a randomized control trial of the whole population except those who do not wish to be involved and those who will be excluded on the grounds of age, ill-health or already diagnosed as leprosy cases.

Nigel Williams 